\title{
Basic income and cultural participation for remote-living Indigenous Australians
}

\author{
Jon Altmana,b and Francis Markhama \\ a Australian National University, Canberra, ACT, Australia \\ b Deakin University, Geelong, VIC, Australia
}

This is the author accepted manuscript of:

Altman, Jon C., and Francis Markham. "Basic Income and Cultural Participation for Remote-Living Indigenous Australians." In Implementing a Basic Income in Australia: Pathways Forward, edited by Elise Klein, Jennifer Mays, and Tim Dunlop, 87-109. Exploring the Basic Income Guarantee. Cham: Palgrave Macmillan, 2019. https://doi.org/10.1007/978-3-030-14378-7_5

\begin{abstract}
In much of remote Australia where a sizable minority of Indigenous people live, labour markets are able to employ only a small fraction of the working-age Indigenous population, a legacy of Australia's settler-colonial past and present. In this chapter, we do two things. First, we describe the Community Development Employment Projects (CDEP) scheme as a basicincome-like program. Using survey data from 2002-03 and 2014-15, we examine the impact of the abolition of the CDEP as a proxy for a future basic income scheme on cultural participation. We find that the existence of CDEP was associated with a modest increase in cultural participation, especially in attendance of sporting carnivals. Second, we argue for the implementation of a true basic income scheme in remote Australia as a first priority for a staged program nationally.
\end{abstract}

\section{Notes on contributors}

Jon Altman is a research professor in anthropology at the Alfred Deakin Institute for Citizenship and Globalisation at Deakin University, Melbourne and an emeritus professor of the Australian National University in the School of Regulation and Global Governance. His research focuses on issues of social and economic justice and appropriate forms of development, especially in remote Indigenous Australia.

Francis Markham is a Research Fellow at the Centre for Aboriginal Economic Policy Research at The Australian National University. An economic geographer, his research interests include Indigenous policy and the political economy of remote Australia. 


\section{Settler-colonialism and surplus populations}

It is symptomatic of Australia's colonial history and post-colonising 1 present that unemployment, and consequently cash poverty, are at dire levels among Indigenous peoples. In 2016, just 46.6 per cent of Indigenous people of working age were employed, compared with 71.8 per cent of non-Indigenous Australians (Venn \& Biddle, 2018); in that same year an estimated 31.4 per cent of Indigenous people were living in households below the poverty line (Markham \& Biddle, 2018a). The economic impoverishment of Indigenous people is particularly acute in what is generally referred to in policy and public discourse as 'remote Australia', that sparsely populated part of the continent where just 1.5 per cent of the nonIndigenous population lives, in contrast to 18.7 per cent of Indigenous peoples (Markham \& Biddle, 2018b).2 Indigenous poverty is growing in prevalence in very remote Australia, with poverty rates reaching 53.4 per cent in 2016 . Working-age Indigenous employment rates in that same region were just 30.1 per cent in the same year. Consequently, Indigenous people are deeply dependent on the Australian state for income support and highly vulnerable to policy fluctuations, sometimes called 'reform' and always presented by the politically powerful as beneficial. Vulnerability to state coercion is greatest in the remotest parts of the country.

The present-day economic deprivation of Indigenous peoples can be attributed in large measure, to the colonisation process (Walter \& Andersen, 2013). The spread of the frontier across the Australian continent was intended to supplant Indigenous peoples and their diverse economies, largely replacing Indigenous livelihoods with colonial capitalism (Altman \& Biddle, 2014; Hunter, 2014). The invasion of Indigenous territory was driven by settlers' desire to control land and its resources, a territoriality that Patrick Wolfe (2006) has argued necessitates the elimination of Indigenous societies, at times by genocidal means, at times by other means. In the process of usurping Indigenous land, sustainable and largely selfsufficient Indigenous economies were everywhere destroyed. In Coulthard's (2014) Marxian account, the separation of Indigenous peoples from control over the means of social reproduction - land - rendered them a dispossessed class, positioned by colonial occupation in opposition to settler society. Indigenous people who survived the triple onslaught of disease, settler violence and the destruction of livelihoods were - from the perspective of the capitalist state - transformed into a surplus population whose labour was peripheral to the economy. While Indigenous people were often dependent on the settler economy to survive, the reverse was rarely true. Indigenous labour was seldom of structural importance to the settler economy except perhaps in the pastoral industry prior to mechanisation (Fijn, Keen, Lloyd, \& Pickering, 2012; Keen, 2010).

However, colonisation was historically and geographically uneven. While the settler project of extraction began in south-eastern Australia in the late 18th century, in remote regions the colonial frontier did not arrive until the late 19th to mid-20th centuries. Successive settlercolonial state policy interventions aimed at 'protection' (to the 1950s) and assimilation (officially in the period 1961-1972) resulted in the centralisation of Indigenous people in missions and government settlements with no economic base. The sparsity of the settler

\footnotetext{
1 Here we use the term post-colonizing after Moreton-Robinson (2015), where the term refers to the active and continuing nature of non-Indigenous colonial occupation of Australia, as distinct from post-colonial contemporary multiculturalism.

${ }_{2}$ Clearly what is termed 'remote' from the perspective of the settler society is not remote for Indigenous people who have occupied these regions for millennia. Relying in this chapter on official statistics, we adopt the Australian Bureau of Statistics' definition of remoteness, a classification that is best considered an index of inaccessibility to population centres and consequently services (Holmes, 2009).
} 
population in remote Australia reflects the unsuitability of the land for intensive commercial agriculture owing to climatic, topographic and other factors. In market-economic terms, the land in remote Australia was and remains of little value as a factor of production, with the notable exemptions of scattered mining enclaves and sprawling pastoral runs.

The marginal economic value of remote lands explains the relative incompleteness of the settler-colonial project of expropriation and elimination in remote parts of Australia. Furthermore, the marginal economic value of remote lands explains the contemporary colonial ambivalence to remote-living Indigenous people, where on the one hand the state has facilitated the return of vast areas of land (Altman \& Markham, 2015), and on the other continues to perpetuate eliminationist policies (Altman, 2018a). A vast 'territory of difference', to borrow Arturo Escobar's (2008) evocative term, now exists across about 40 per cent of Australia's landmass. In this region, less than 20 per cent of the population are settlers and almost all land is controlled with variable rights of exclusion and control by Indigenous land owners (Altman \& Markham, 2015).

The economy of this 'territory of difference' is overdetermined by its history. Its primary residents are Indigenous peoples' whose self-sufficiency was destroyed by colonial invasion, and who now inhabit land that is seldom of value to the capitalist market economy.

Consequently, the demand for waged labour in these places is chronically deficient. Fewer than one-in-three Indigenous people in very remote Australia are in formal employment, and 70 per cent of those unemployed report a lack of local jobs as the most important barrier preventing them from finding paid work (Altman \& Markham, 2018). Half of the jobs that do exist are in the state-funded provision of education, health and social care and public administration, with a further 10 per cent of jobs in the Indigenous not-for-profit sector.3 Put simply, in the remotest parts of Australia, the market provides paid employment to only 12 per cent of Indigenous people of working age, with the majority forming a surplus population whose labour is of no apparent value for capital accumulation. Instead, remote-living Indigenous people operate by necessity and by choice in a 'hybrid economy', that includes both state and market sectors but also a customary or non-market sector with similarities to precolonial hunting and gathering for livelihood (Altman, 2009). Although the closure of the market is far from complete even in the metropolitan Global North (Gibson-Graham, 1996), in very remote Australia the mainstream labour market has comprehensively failed and continues to fail to provide a livelihood for the vast majority of its Indigenous inhabitants.

\section{The Community Development Employment Projects scheme as basic income}

It was this context of barely-existing labour markets and few prospects for market-linked economic development the long-running Community Development Employment Projects scheme (henceforth CDEP) was introduced in 1977. CDEP was innovatively designed to allow the provision of block grants from the Commonwealth government to local Indigenous organisations such as councils or incorporated bodies to create part-time jobs for Indigenous people. But where there were no work opportunities, especially when people lived at small outstation or homeland communities, CDEP was paid as a basic income with no work requirements beyond those negotiated with community leaders (Altman, 2016). CDEP was principally funded from the notional social security benefit entitlements of participants.

3 In the 2016 Census, $49.8 \%$ of employed Indigenous people living Very Remote areas were employed in ANZIC Divisions 'O', 'P' and 'Q', a classification which excludes a further $11.7 \%$ working in the largely statefunded Indigenous sector, classified as ‘S9559’ or 'Other Interest Group Services’. 
Significantly, those participating in the scheme were paid award wages and were classified as employed. The scheme was extremely successful according to a number of official metrics. At its peak in 2003, it provided one-third of the jobs occupied by Indigenous people nationally (Jordan \& Altman, 2016). Despite these successes, CDEP was effectively abolished from 1 July 2013 with the establishment of the work-for-the-dole linked Remote Jobs and Communities Program, with a few remnant 'grandfathered' participants continuing till 30 June 2015.4 This abolition coincided with a shift in government policy that critiqued any form of self-determination and saw Indigenous policy take a neoliberal paternalist turn (see Jordan, 2016). In its place, successive governments in the last decade have implemented punitive workfare style schemes that have attempted to train and discipline Indigenous people to enter labour markets that have few or no jobs to offer.

This chapter affords no opportunity to properly outline the history and character of CDEP (but see Altman, 2016; Altman \& Sanders, 1991; Jordan, 2016; Morphy \& Sanders, 2004; Sanders, 1988, 2012). Instead, we reiterate an argument made elsewhere (Altman, 2016; Altman \& Klein, 2018) that in its institutional design, CDEP had certain characteristics that made it similar to both basic income and jobs guarantee schemes. CDEP had four distinguishing features: it was community controlled; participation was voluntary, it was not workfare; it was flexible allowing for culturally-productive and valued forms of labour falling outside the formal economy; and it emphasised, community development allowing Indigenous organisations the autonomy to pursue forms of 'development' that aligned with local aspirations and priorities focus (Altman \& Klein, 2018). CDEP was not designed as a basic income scheme, but over its life it was refigured to operate in this way. Indeed, CDEP became the nearest institutional arrangement to basic income seen in Australia to date.

Statistical studies of the impacts of CDEP during this period have typically compared standard economic indicators of scheme participants with non-participants at a single point in time. These studies have found that those participating in CDEP had higher average incomes than the unemployed or those not in the labour force (Altman \& Gray, 2000; Altman, Gray, \& Levitus, 2005; Sanders, 1997) and reduced financial stress (Hunter, 2009). Other findings include an increased likelihood for CDEP participants to have undertaken vocation education than the unemployed or those not in the labour force (Altman et al., 2005; Hunter, 2009) and a decreased incidence of social harms such as violence victimisation, arrest and substance abuse (Hunter, 2009).

One previous study examined customary and cultural (non-market) activities undertaken by CDEP participants (Altman et al., 2005). It found that more CDEP participants engaged in such activities than either the unemployed or those in mainstream employment. CDEP is likely to have directly and indirectly supported Indigenous cultural life in several ways. Most directly, CDEP participants may have been tasked with customary activities such as land management or cultural production as part of their CDEP duties. Indirectly, the CDEP may have subsidised cultural activities through the provision of cash incomes that were greater than those available to the unemployed. These incomes may have been expended on vehicles and fuel essential today for engagement in customary and cultural activities. Furthermore, CDEP strengthened the Indigenous sector more broadly, especially those organisations which administered the scheme. This increased organisational capacity is likely to have also increased the ability of organisations to support cultural participation (Altman, 2016). That such an effect might exist is hardly surprising given that one of the primary aims of basic 
income schemes is to increase the capacity of people to pursue their individual and collective goals beyond those mandated by the labour market (Parijs, 2017).

However, it is difficult to attribute the correlations between CDEP participation and customary and cultural activities identified by Altman et al. (2005) just to CDEP. Because of the cross-sectional nature of this research, it is possible that some of the differences between the outcomes for CDEP participants compared to non-participants is the result of underlying differences between these groups of individuals that are unrelated to CDEP. It is always important not to confuse statistical correlation with causality. As an example, substance abuse might be lower among CDEP participants than the unemployed because substance abuse precludes participation rather than because CDEP participation reduced the rate of substance abuse (Hunter, 2009). Similar critiques might be made of other correlations between customary and cultural activities and CDEP. The findings for other outcomes appear to be more robust, due to the likely monodirectionality of plausible causal effects. For example, the links between CDEP and income are much more likely to be causal given that CDEP participation was directly remunerated with award wages.

In our view, the abolition of CDEP and its replacement with a punitive workfare regime is regrettable for a number of reasons including that it deepens the poverty experienced by Indigenous people who are unemployed (Altman and Markham 2018; Jordan, 2016). But this abolition does afford a rare opportunity to investigate how the scheme that we might take as a proxy for basic income effected participants. This is what social scientists sometimes refer to as a 'natural experiment', an unintended possibility to check on the effects of a scheme because of the availability of before and after information. No quantitative studies of the impact of the abolition of CDEP have been published, with the single exception being Venn and Biddle's (2018) analysis of census data. Examining the marked decline in Indigenous employment outcomes in remote areas between 2011 and 2016 Venn and Biddle attribute most, but not all, job losses to the abolition of CDEP.

In this chapter we examine the impact of the withdrawal of the CDEP, in order to learn more about the likely impact of a future basic-income-like program. We investigate the relationship between access to a basic-income-like scheme and cultural flourishing. Specifically, we analyse the impact of the abolition of CDEP on three indicators of cultural activity in the National Aboriginal and Torres Strait Islander Social Survey (NATSISS) of 2002 and 2014. A simple before-and-after description of the prevalence of these three indicators is supplemented by an analysis based on a propensity score matching approach used to classify Indigenous persons according to their likelihood of participating in CDEP on the basis of their socio-demographic characteristics. Changes in the prevalence of cultural participation are then disaggregated by the propensity to participate in a CDEP-like program.

\section{Methods}

The NATSISS is a nationally representative sample survey of the Indigenous population living in private dwellings, conducted by the Australian Bureau of Statistics (ABS). It asks Aboriginal or Torres Strait Islander household members questions about their socioeconomic circumstances, aspects of Indigenous cultures, and their health and well-being. It is conducted every six years, allowing for the comparison of snapshots of the Indigenous population at different points in time. We chose the 2002 NATSISS and the 2014 NATSISS intentionally, as in the former CDEP was at its peak and in the latter, it was abolished across most of remote Australia. The 2014 NATSISS interviewed 11,178 individuals from 6,611 households, with an in-scope household response rate of 80 per cent. Interviews were 
conducted between September 2014 and June 2015. The 2002 NATSISS interviewed 9,359 Indigenous persons in 5,887 households between August 2002 and April 2003, with a household response rate of 79 per cent. Further information on survey design is available from the ABS $(2005,2016)$.

Our analysis focuses on remote areas of Australia, where CDEP was most prevalent. Only the responses of Indigenous people of working age (i.e. aged 15-64 years) were considered. In the 2002 NATSISS, 3,886 respondents met these inclusion criteria, with 2,317 eligible survey respondents in the 2014 NATSISS.

Both the 2002 and 2014 NATSISS interviews asked respondents about their participation in 'cultural' activities: whether they had attended ceremonies and sports carnivals, produced art or craft, or hunted or fished. All questions referred to participation in these cultural activities within the previous twelve months, except that in the 2002 NATSISS the question on hunting and fishing referred to participation within the previous three months.5 Although the questions differed slightly between surveys, wording was similar enough to make the results directly comparable, with the exception of the important livelihood question about hunting and fish (see Table 1).

We expect that cultural participation in ceremonies, sporting carnivals and customary food gathering would be higher during the existence of a basic-income-like program for several reasons. Relative to those in regular employment, the CDEP generally afforded participants a greater degree of flexibility to attend to cultural events, facilitating cultural participation. Relative to the non-employed for whom workplace flexibility is not an issue, the CDEP provided resources which are likely to have assisted with the financial costs of cultural participation, such as petrol and car maintenance. The case of art and craft production is slightly different. In many notable instances, the production of arts and crafts was undertaken as a CDEP activity, with participants receiving an income from an art centre for such production (Altman, 2005). In other places, CDEP participants may have worked in a support role in art centres, facilitating increased cultural production by others.

5 Altman, Buchanan \& Biddle (2006, p. 149) were critical of the 2002 NATSISS for potentially ignoring the economic significance of 'cultural' work like hunting and gathering and art and crafts, a critique that was ignored in subsequent 2008 and 2014 surveys. 
Table 1: Questions about participation in cultural activities in the 2002 and 2014 NATSISS

\begin{tabular}{|c|c|c|}
\hline & 2002 & 2014 \\
\hline $\begin{array}{l}\text { Attended } \\
\text { ceremonies }\end{array}$ & $\begin{array}{l}\text { In the last } 12 \text { months, have you gone to any } \\
\text { Aboriginal or Torres Strait Islander } \\
\text { ceremonies? }\end{array}$ & $\begin{array}{l}\text { In the last } 12 \text { months, have you gone to or } \\
\text { been involved in any of these Aboriginal or } \\
\text { Torres Strait Islander cultural activities or } \\
\text { ceremonies: Ceremonies? }\end{array}$ \\
\hline $\begin{array}{l}\text { Attended } \\
\text { sports } \\
\text { carnivals }\end{array}$ & $\begin{array}{l}\text { In the last } 12 \text { months, have you gone to any } \\
\text { Aboriginal or Torres Strait Islander sports } \\
\text { carnivals? }\end{array}$ & $\begin{array}{l}\text { In the last } 12 \text { months, have you gone to or } \\
\text { been involved in any of these Aboriginal or } \\
\text { Torres Strait Islander cultural activities or } \\
\text { ceremonies: Sports carnivals? }\end{array}$ \\
\hline $\begin{array}{l}\text { Produced art } \\
\text { or craft }\end{array}$ & $\begin{array}{l}\text { In the last year, did you make any Aboriginal } \\
\text { or Torres Strait Islander arts or crafts? } \\
\text { (including activities done as part of your job) }\end{array}$ & $\begin{array}{l}\text { Have you done any of the following activities } \\
\text { in the past year: Made Aboriginal or Torres } \\
\text { Strait Islander arts or crafts? }\end{array}$ \\
\hline $\begin{array}{l}\text { Hunted or } \\
\text { fished }\end{array}$ & $\begin{array}{l}\text { In the last } 3 \text { months, have you done anything } \\
\text { else with other people such as going fishing } \\
\text { or hunting in a group? }\end{array}$ & $\begin{array}{l}\text { Have you done any of the following activities } \\
\text { in the past year: Hunted? Fished? }\end{array}$ \\
\hline
\end{tabular}

Responses to questions about cultural participation were tabulated and compared to show trends in cultural participation between 2002-03 and 2014-15. However, it is difficult to attribute trends detected using this approach to the abolition of CDEP. Cultural participation may have changed between 2002 and 2015 for reasons unrelated to the CDEP. For example, art and craft production may have declined due to the crash of the Indigenous art market in the aftermath of the Global Financial Crisis (Day, 2014; Office of the Registrar of Indigenous Corporations, 2012).

Consequently, a propensity score matching approach was taken to examine changes in cultural participation. Ideally, we would like to compare cultural participation between CDEP participants and non-participants in 2002 and 2014. However, directly identifying CDEP participants in the 2014 NATSISS is not possible, as the scheme no longer existed at that time. If suitable longitudinal data existed, we might track the changes to cultural participation after the abolition of CDEP among CDEP participants and compare that to changes in cultural participation among CDEP non-participants. Yet, no such data are available. Consequently, we use propensity score matching to build a model of the likelihood that individuals would participate in CDEP in 2002,6 and apply that model to predict CDEP participation propensity in both the 2002 and 2014 data.

Based on this model, we classify respondents in 2002 and 2014 in terms of their likelihood to participate in CDEP if it existed. Specifically, model-based predictions of propensity to participate in CDEP were calculated, and individuals' propensity was grouped into quintiles, from least likely to participate in CDEP (quintile 1) to most likely to participate in CDEP (quintile 5). Using these propensity scores, we can compare changes in cultural participation between likely CDEP participants and unlikely CDEP participants in a consistent way

6 Specifically, the propensity of working-age remote-living Indigenous persons to participate in the CDEP in the 2002 NATSSIS was modelled using logistic regression. Our model predicted CDEP participation of individuals on the basis of their age; sex; state or territory of residence; whether English was the main language spoken at home; whether the persons identifies with a specific Indigenous tribe, clan, language group, regional group or mission; self-assessed health status; whether the person had a profound disability; whether the person lived in a house that was owned or being purchased, rented privately, or in social housing; whether the person ever attended high school; and whether the person had attained a post-school qualification at Certificate III level or higher. Interaction terms and quadratic terms were used where appropriate. All predictor variables in the model were significantly associated with CDEP participation. McFadden pseudo-R2 for the model was 0.12. 
between 2002 and 2014. All analyses were conducted using individual-level population weights calculated by the ABS.

\section{Results}

As shown in previous research (for example, Venn \& Biddle, 2018), the abolition of CDEP coincided with a decrease in employment among the Indigenous working-age population (see Table 2). While employment outside CDEP rose by 16.9 per cent, employment in total fell by 17.3 per cent. The fall in employment resulted in both a rise in unemployment (an increase of $7.9 \%$ ) and the proportion of the population outside the labour force (an increase of $9.5 \%$ ).

Table 2: Labour force status of Indigenous people aged 15-64 living in remote Australia, before and after the abolition of CDEP, from the NATSISS

\begin{tabular}{lrr}
\hline & $2002(\%)$ & $2014(\%)$ \\
\cline { 2 - 3 } Employed in CDEP scheme & 34.2 & - \\
Employed outside CDEP & 20.2 & 37.1 \\
Unemployed * & 6.2 & 14.1 \\
Not in labour force & 39.4 & 48.9 \\
\hline Notes: * The percentage unemployed is a much lower figure than the \\
familiar 'unemployment rate', as the latter does not include those not in \\
the labour force in the denominator. The unemployment rate was $10.2 \%$ \\
in 2002 and 27.5\% in 2014.
\end{tabular}

These changes in remote employment are disaggregated by propensity to participate in CDEP in Table 3. It shows that the model predicted CDEP participation in 2002 with moderate accuracy. In consequence, the abolition of the CDEP affected the group most likely to participate in it the hardest. Unemployment among those most likely to participate in CDEP rose by 13.7 percentage points, compared to 5.6 percentage points among those least likely to participate in CDEP. Labour force participation fell dramatically among those most likely to participate in the CDEP (25.0 percentage points), compared to a modest decrease among those unlikely to participate in the CDEP (2.7 percentage points).

Table 3: Labour force status of Indigenous people aged 15-64 living in remote Australia, before and after the abolition of CDEP, by propensity to participate in CDEP if it existed, from the NATSISS

\begin{tabular}{|c|c|c|c|c|c|c|}
\hline & & $\begin{array}{c}\text { Employed } \\
\text { in CDEP } \\
\text { scheme } \\
(\%)\end{array}$ & $\begin{array}{c}\text { Employed } \\
\text { outside } \\
\text { CDEP } \\
(\%) \\
\end{array}$ & $\begin{array}{c}\text { Employed, } \\
\text { total } \\
(\%) \\
\end{array}$ & Unemployed* & $\begin{array}{c}\text { Not in the } \\
\text { labour force } \\
(\%)\end{array}$ \\
\hline \multirow[t]{5}{*}{2002} & $\begin{array}{l}\text { Quintile } 1 \text { (least likely to } \\
\text { participate in CDEP) }\end{array}$ & 10.5 & 38.1 & 48.6 & 4.7 & 46.7 \\
\hline & Quintile 2 & 20.4 & 25.0 & 45.4 & 5.9 & 48.7 \\
\hline & Quintile 3 & 32.0 & 15.1 & 47.1 & 4.9 & 47.0 \\
\hline & Quintile 4 & 46.3 & 11.0 & 57.3 & 7.0 & 35.7 \\
\hline & $\begin{array}{l}\text { Quintile } 5 \text { (most likely to } \\
\text { participate in CDEP) }\end{array}$ & 59.2 & 12.2 & 71.4 & 7.4 & 21.1 \\
\hline \multirow[t]{5}{*}{2014} & $\begin{array}{l}\text { Quintile } 1 \text { (least likely to } \\
\text { participate in CDEP) }\end{array}$ & - & 45.7 & 45.7 & 10.3 & 44.0 \\
\hline & Quintile 2 & - & 38.1 & 38.1 & 10.2 & 52.7 \\
\hline & Quintile 3 & - & 32.9 & 32.9 & 13.2 & 53.9 \\
\hline & Quintile 4 & - & 32.9 & 32.9 & 16.9 & 50.2 \\
\hline & $\begin{array}{l}\text { Quintile } 5 \text { (most likely to } \\
\text { participate in CDEP) }\end{array}$ & - & 32.8 & 32.8 & 21.1 & 46.1 \\
\hline
\end{tabular}

Notes: * The percentage unemployed is a much lower figure than the familiar 'unemployment rate', as the latter does not include those not in the labour force in the denominator. 
Table 4 shows that the period 2002 to 2014 saw a substantial drop in participation in cultural activities among remote-living Indigenous people surveyed by the NATSISS. Specifically, 12-month participation in ceremonies and sports carnivals dropped by 12.2 per cent and 13.4 per cent respectively. Participation in art and craft production only declined slightly over this period, despite the downturn in the Indigenous art market. The apparent increase in hunting and fishing is deceptive, as the 2002 and 2014 NATSISS questionnaires measured participation over different time periods.

Table 4: Participation in cultural activities by Indigenous people aged 15-64 living in remote Australia, before and after the abolition of CDEP, from the NATSISS

\begin{tabular}{lcc}
\hline & $\begin{array}{c}2002 \\
(\%)\end{array}$ & $\begin{array}{c}2014 \\
(\%)\end{array}$ \\
\cline { 2 - 3 } & 44.9 & 32.7 \\
Attended ceremonies & 54.2 & 40.8 \\
Attended sports carnivals & 18.7 & 17.5 \\
Produced art or craft & 52.0 & 79.2 \\
Hunted or fished * & & \\
\hline $\begin{array}{l}\text { Notes: * The 2002 and 2014 participation rates } \\
\text { for hunting or fishing are not directly comparable, }\end{array}$ \\
$\begin{array}{l}\text { as the 2002 NATSISS asked about 3-month } \\
\text { participation, where the 2014 NATSISS asked } \\
\text { about 12-month participation. }\end{array}$ \\
\hline
\end{tabular}

The distribution of these changed participation rates by propensity to participate in CDEP is plotted in Figures 1 to 4 . Figure 1 shows little reduction in ceremony attendance by propensity to participate in the CDEP, with a fairly consistent drop of around 10 percentage points across propensity quintiles.

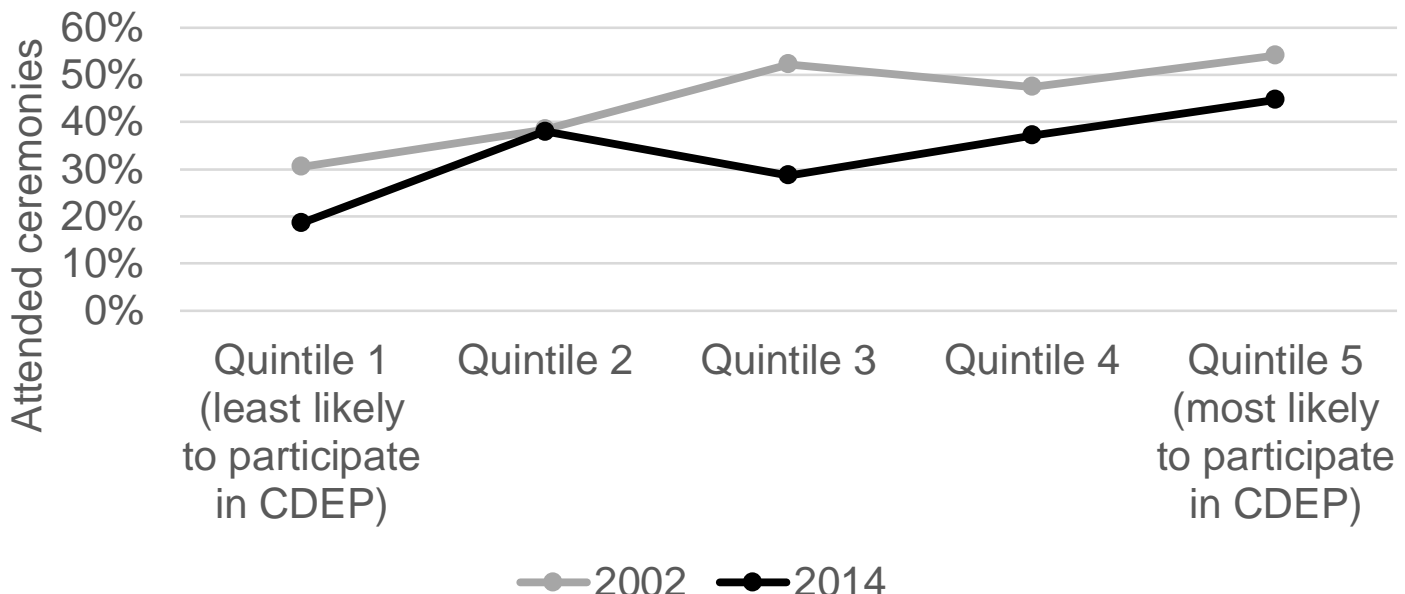

Figure 1: Attendance of ceremonies in previous 12 months by Indigenous people aged 15-64 living in remote Australia, before and after the abolition of CDEP, by propensity to participate in CDEP if it existed, from the NATSISS

Figure 2, however, shows that the reduction in the propensity to attend sports carnivals that is strongly patterned by propensity to participate in the CDEP. For those least likely to participate in the CDEP, there was little reduction in the sports carnival attendance (1.2 percentage points). For those in Quintiles 2, 3 and 4, however, the reduction in attendance was more substantial $(13.2,11.6$, and 11.5 percentage points respectively). Finally, for those most likely to participate in CDEP, the reduction in participation was most dramatic, falling 19.2 percentage points. 


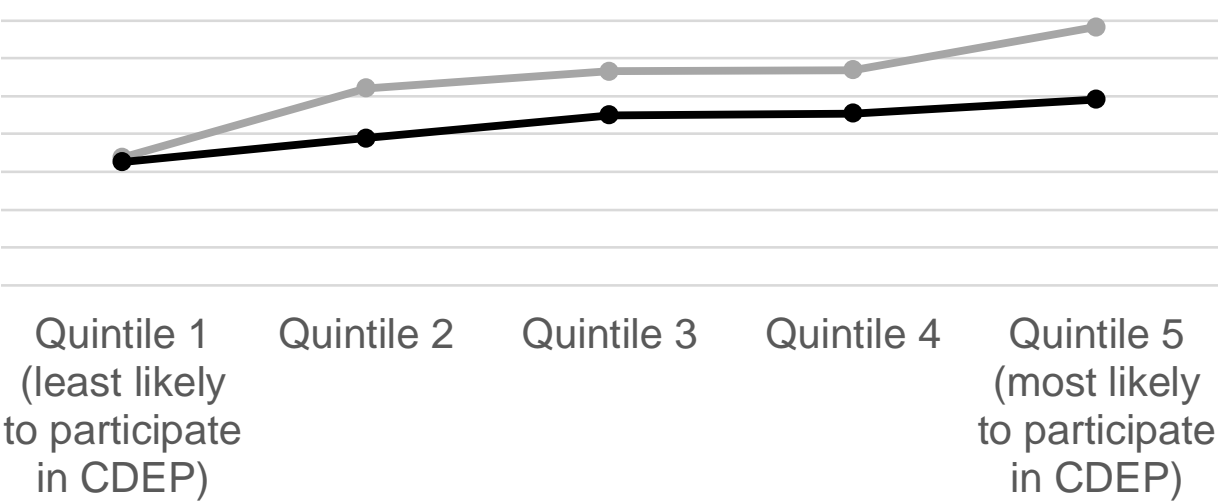

$-2002 \rightarrow 2014$

Figure 2: Attendance of sports carnivals in previous 12 months by Indigenous people aged 15-64 living in remote Australia, before and after the abolition of CDEP, by propensity to participate in CDEP if it existed, from the NATSISS

In the case of arts and craft production, no clear trend emerged when examined by CDEP participation. Figure 3 shows that while production increased for Quintile 2 between 2002 and 2014, it decreased for Quintile 3.
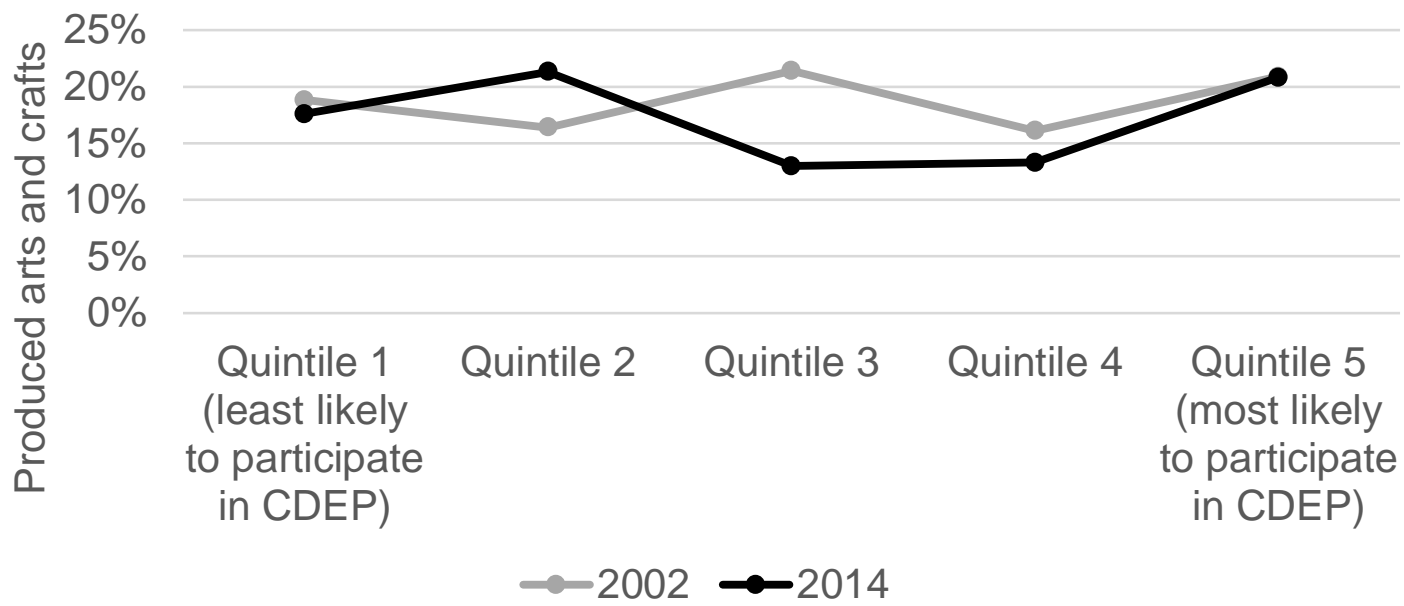

Figure 3: Production of arts and crafts in previous 12 months by Indigenous people aged 15-64 living in remote Australia, before and after the abolition of CDEP, by propensity to participate in CDEP if it existed, from the NATSISS

Finally, in the case of hunting and fishing, interpretation is compromised by the changing time periods interrogated in the questions between the 2002 and 2014, meaning that participation rates cannot be directly compared. However, the slopes of the two lines in Figure 4 can be compared. In 2002, those most likely to participate in CDEP were more likely to hunt or fish in the previous 3-months than those who were unlikely to participate in the CDEP. Specifically, 19.2 per cent of those in Quintile 1 hunted or fished in the previous 3 months in 2002, compared to 69.7 per cent in Quintile 5. By 2014, that gradient had decreased significantly, with 65.2 per cent of those in Quintile 1 hunting or fishing in the previous 12 months, compared with 85.1 per cent of those in Quintile 5. While some of this pattern may be the result of those in Quintile 5 having a greater frequency of hunting and fishing, it is also consistent with a reduction in the prevalence of hunting and fishing between 2002 and 2014 among those most likely to participate in CDEP. 

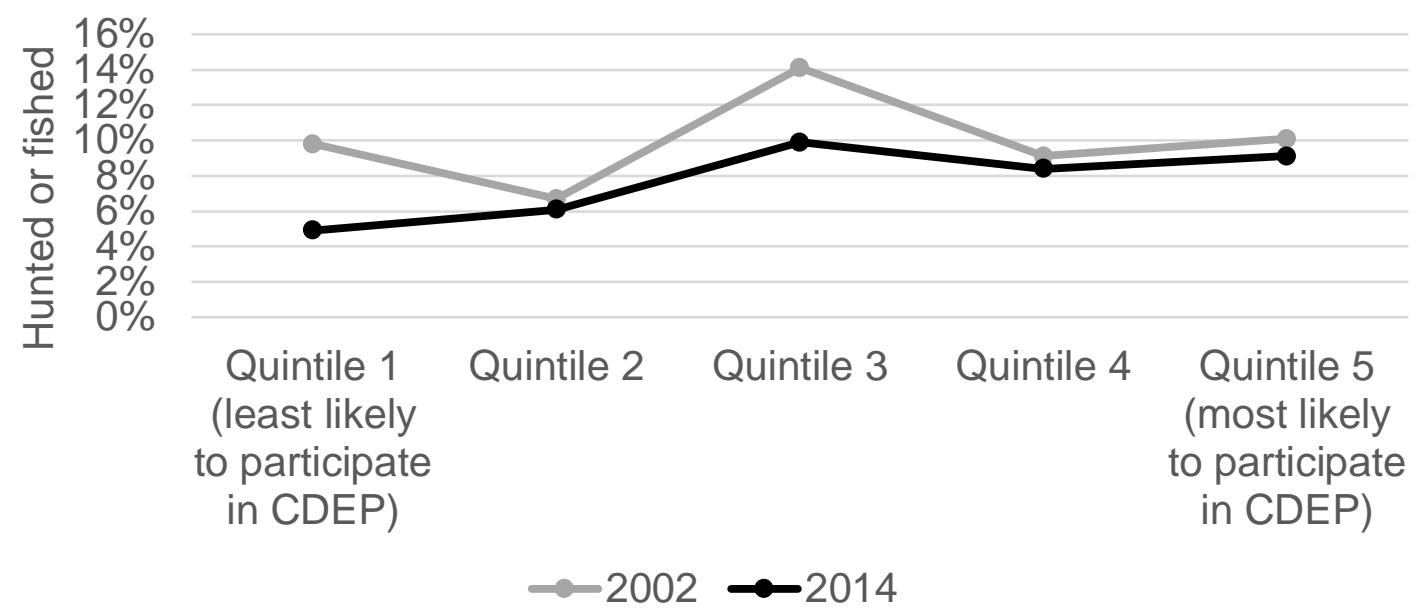

Figure 4: Hunting and fishing by Indigenous people aged 15-64 living in remote Australia, before and after the abolition of CDEP, by propensity to participate in CDEP if it existed, from the NATSISS. Note that 2002 data refer to hunting or fishing in the previous 3 months, while 2014 data refer to hunting or fishing in the previous 12 months.

\section{Discussion and concluding comments}

The abolition of CDEP, a long-running Commonwealth government program with basic income characteristics, has had extremely negative consequences for the employment of remote-living Indigenous people. This lamentable outcome is entirely unsurprising, given that CDEP provided employment for more than a third of the remote working-age Indigenous population in 2002. However, by examining the effects of CDEP, abolition we can learn something about the likely results if a basic income program were introduced in remote Australia.

The abolition of CDEP coincided with a substantial drop in reported participation in cultural activities, especially attendance at ceremonies (12.2 percentage points) and attendance at sports carnivals (13.4 percentage points). The prevalence of the reported production of arts and crafts was more stable when the scheme was abolished.

Because it is unclear to what extent these reported changes in the rate of cultural participation are the result of the abolition of CDEP, we compared the change in the rate of cultural participation by propensity to participate in CDEP. Clear patterns emerged in participation in sporting carnivals, with a steep decline in participation among those most likely to participate in CDEP and almost no decline among those least likely to participate in CDEP. Such a pattern indicates that the abolition of CDEP played an important role in reducing cultural participation in this domain. Conversely, there was little evidence that changes in the rate of participation in ceremonies or arts and craft production was associated with the abolition of CDEP. It seems that other factors caused the decline in the prevalence of ceremonial attendance. Finally, the case of hunting and fishing is more difficult to interpret due to changes to the survey questionnaire. The evidence is consistent with declining patterns of food gathering and the abolition of CDEP, but it is unclear if customary food harvesting did 
decline over this period. The results for hunting and fishing are far from conclusive because of inconsistencies in the questions asked between the 2002 and 2014 surveys; the empirical results may be attributable to CDEP participants engaging in hunting and fishing activities more frequently than non-participants.

One caveat around these findings is that the propensity matching approach used does not precisely classify survey respondents by CDEP-participation propensity. One consequence of this is that the effects found in this study are likely to be underestimated by as much as 80 per cent. Future research using this approach might benefit from methods found in the intentionto-treat literature to adjust estimated effects to the correct magnitude (Angrist \& Pischke, 2014).

CDEP was an innovative program designed in large measure in recognition of the absence of sufficient jobs in remote Australia that has resulted from the uneven geography of settlercolonisation. The abolition of CDEP has seen a substantial increase in unemployment in remote Australia and has resulted in many Indigenous people withdrawing from the labour force. This withdrawal provides a likely explanation for rising poverty rates in remote Australia (Markham \& Biddle 2018a).

In the absence of CDEP, new approaches are needed both to alleviate poverty and to facilitate the cultural flourishing of remote living Indigenous people. All people have a right to remain on the land that they own, especially Indigenous people living remotely who have particularly strong ontological links to their ancestral lands. The exercise of such a right to live on their lands (or to leave if they so wish) requires either economic redistribution or state support of Indigenous forms of livelihood where labour market and commercial opportunity might be absent. State support might come directly through payments to alleviate cash poverty and indirectly through the support of sustainable livelihoods.

One way for this to occur is via the introduction of a scheme to provide a minimum guaranteed income alongside supplementary opportunities for individual or collective enterprise. This is how CDEP operated when it worked well (see, for examples, the case studies in Morphy \& Sanders, 2004; Jordan, 2016). This chapter demonstrates that the benefits of the introduction of a basic income scheme would not be limited to poverty alleviation but would also lie in the realm of cultural participation. To the extent that a basic income scheme would reverse the economic, social and cultural harms caused by the abolition of CDEP, any basic income program would be expected to increase cultural participation. Such increased participation is likely to include country food self-provisioning, which not only maintains Indigenous cultural vitality, but could also play an important economic role in poverty alleviation. Policy that alleviates the material deprivation of Indigenous people will also lead to their cultural flourishing.

The implementation of an Indigenous-specific basic income scheme nationally is likely to encounter a range of practical difficulties. First, political resistance from elements of nonIndigenous society would be expected, with accusations of 'reverse racism' likely. Such objections are unjust - Australia has never paid reparations to Indigenous peoples for their dispossession and mistreatment, except in the case of manifestly inadequate stolen wages redress schemes (Kinnane, Harrison, \& Reinecke, 2015). A great debt of reparations for stolen and degraded land (Altman 2018b), violence and other numerous forms of expropriation is owed by the state to Australia's Indigenous peoples. In this context, a national Indigenous basic income might be construed as offering those whose material 
interests have been harmed by colonialisation a rightful share of Australia's wealth (Ferguson 2015). Second and more problematically, the introduction of a national, Indigenous-only basic income scheme of any serious magnitude would face the difficulty of determining eligibility. A single criterion of self-identification would be too imprecise to be useful, while the three-criteria definition of Indigeneity that includes recognition by other Aboriginal and Torres Strait Islander peoples may be overly exclusionary and lead to political conflict (Carlson, 2016).

While remaining in favour of reparations nationally as a separate policy goal, we argue that an initial basic income scheme limited to those remote areas with dysfunctional to nonexistent labour markets is more readily achievable and politically palatable. Such a proposal - which would explicitly not be a form of redress - would have several advantages over a national Indigenous basic income scheme. First, it would be more affordable, as it would cover well under 20 per cent of the Indigenous population. Basic income costs would be offset by a substantial degree by the relatively high rates of welfare receipt in remote areas, and would enable the abolition of a futile and punitive workfare scheme which costs over $\$ 10,000$ per participant per year simply to administer (The Auditor General, 2017). Second, because eligibility for a scheme would be assessed on the basis of geographical labour markets rather than ethnic origin, difficulties in determining the Indigeneity of citizens would be eliminated, even though we would anticipate that the vast majority of recipients would be Indigenous. For this reason, this scheme would be less likely to encounter political resistance, either from Indigenous peoples themselves or from populist opponents.

We remain in favour of a universal basic income scheme for Australia as a whole. However, such a scheme need not be implemented in a single phase. A remote basic income scheme might be considered as the first step towards a truly universal scheme. Our geographic targeting might easily precede or complement the demographic targeting suggested by SpiesButcher and Henderson (2019) as the first priority for implementing basic income in Australia.

The parlous state of remote labour markets makes the introduction of a basic income scheme in remote Australia a matter of policy urgency given the inappropriateness of the current approach based on the unrealistic expectation that people will find standard forms of mainstream work in situations where no or few opportunities exist. The analysis in this chapter supports the broader proposition that the introduction of a basic income scheme could lead to self-determined human flourishing (Parijs, 2017). Rather than experiencing the discipline (and associated punishment) imposed by the wage-labour relationship in situations where there are few jobs, individuals could be liberated to pursue the activities of greatest importance to them, activities that will generate economic, social and cultural benefits not just to individuals but also to their families and communities. 


\section{References}

Altman, J. C. (2005). Brokering Aboriginal art: a critical perspective on marketing, institutions, and the state (Kenneth Myer Lecture in Arts \& Entertainment Management). Geelong, Vic: Deakin University.

Altman, J. C. (2009). The hybrid economy and anthropological engagements with policy discourse: A brief reflection. The Australian Journal of Anthropology, 20(3), 318329. https://doi.org/10.1111/j.1757-6547.2009.00039.x

Altman, J. C. (2016). Basic Income for Remote Indigenous Australians: Prospects for a Livelihoods Approach in Neoliberal Times. In J. Mays, G. Marston, \& J. Tomlinson (Eds.), Basic income in Australia and New Zealand: perspectives from the neoliberal frontier (pp. 179-205). Houndmills; New York: Palgrave Macmillan.

Altman J. C. (2018a). Raphael Lemkin in the Outback: The State Project to Eliminate Homelands Living in Remote Indigenous Australia. Oceania, in press.

Altman J. C. (2018b). Threatened Aboriginal country and the right to proper redress. Land Rights News - Northern Edition, May 2018, 19-21.

Altman, J. C., \& Biddle, N. (2014). Refiguring Indigenous economies: A 21st-century perspective. In S. Ville \& G. Withers (Eds.), The Cambridge Economic History of Australia (pp. 530-554). Melbourne: Cambridge University Press. https://doi.org/10.1017/CHO9781107445222.008

Altman, J. C., Buchanan, G., \& Biddle, N. (2006). The real 'real' economy in remote Australia. In Assessing the evidence on Indigenous socioeconomic outcomes: A focus on the 2002 NATSISS (pp. 139-152). Canberra: ANU Press.

Altman, J. C., \& Gray, M. (2000). The effects of the CDEP scheme on the economic status of Indigenous Australians: some analyses using the 1996 Census (Discussion Paper No. 195) (p. 36). Canberra: Centre for Aboriginal Economic Policy Research, ANU. 
Altman, J. C., Gray, M., \& Levitus, R. (2005). Policy issues for the Community Development Employment Projects scheme in rural and remote Australia (Discussion Paper No. 271). Canberra: Centre for Aboriginal Economic Policy Research, ANU.

Altman, J. C., \& Klein, E. (2018). Lessons from a basic income programme for Indigenous Australians. Oxford Development Studies, 46(1), 132-146. https://doi.org/10.1080/13600818.2017.1329413

Altman, J. C., \& Markham, F. (2015). Burgeoning Indigenous land ownership: Diverse values and strategic potentialities. In Sean Brennan, Megan Davis, Brendan Edgeworth, \& Leon Terrill (Eds.), Native Title from Mabo to Akiba: A vehicle for change and empowerment (pp. 126-142). Sydney: Federation Press.

Altman, J. C., \& Markham, F. (2018). Submission to the Senate Select Committee Inquiry into the Future of Work and Workers (Submission No. 34) (p. 10). Canberra: Parliament of Australia. Retrieved from http://hdl.handle.net/1885/148244

Altman, J. C., \& Sanders, W. (1991). The CDEP Scheme: Administrative and Policy Issues. Australian Journal of Public Administration, 50(4), 515-525. https://doi.org/10.1111/j.1467-8500.1991.tb02323.x

Angrist, J. D., \& Pischke, J.-S. (2014). Mastering 'Metrics: The Path from Cause to Effect (with French flaps edition). Princeton; Oxford: Princeton University Press.

Australian Bureau of Statistics. (2005). National Aboriginal and Torres Strait Islander Social Survey: Expanded Confidentialised Unit Record File, Technical Paper, 2002 (Cat. No. 4720.0). Canberra: Australian Bureau of Statistics. Retrieved from http://www.abs.gov.au/AUSSTATS/abs@.nsf/allprimarymainfeatures/35785040B089 9214CA2576D50016BB4C?opendocument

Australian Bureau of Statistics. (2016). National Aboriginal and Torres Strait Islander Social Survey: User Guide, 2014-15 (Cat. No. 4720.0). Canberra: Australian Bureau of 
Statistics. Retrieved from

http://www.abs.gov.au/AUSSTATS/abs@.nsf/allprimarymainfeatures/880A750EFFD E2611CA2570BF007B1CD4?opendocument

Spies-Butcher, B., \& Henderson, T. (2019). Stepping Stones to an Australian Basic Income.

In E. Klein, J. Mays, \& T. Dunlop (Eds.), Implementing a Basic Income in Australia: Pathways Forward (pp. 163-178). Springer International Publishing. https://doi.org/10.1007/978-3-030-14378-7_9

Carlson, B. (2016). The Politics of Identity: Who Counts as Aboriginal Today? Canberra, A.C.T: Aboriginal Studies Press.

Day, D. (2014). The Art Market down under: A Case Study of Australian Aboriginal Art Market Regulation and U.S Art Market Implication Note. Cardozo Journal of International and Comparative Law, 23, 133-164.

Escobar, A. (2008). Territories of Difference: Place, Movements, Life, Redes. Durham: Duke University Press Books.

Ferguson, J. (2015). Give a Man a Fish: Reflections on the New Politics of Distribution. Durham; London: Duke University Press.

Fijn, N., Keen, I., Lloyd, C., \& Pickering, M. (Eds.). (2012). Indigenous Participation in Australian Economies II. Canberra: ANU Press.

Gibson-Graham, J. K. (1996). The end of capitalism (as we knew it): A feminist critique of political economy. Cambridge, Mass: Blackwell Publishers.

Holmes, J. (2009). Rethinking Remoteness. Geographical Research, 47(3), 331-333. https://doi.org/10.1111/j.1745-5871.2009.00603.x

Hunter, B. (2009). A half-hearted defence of the CDEP scheme. Family Matters, 81, 43-54. 
Hunter, B. (2014). The Aboriginal legacy. In S. Ville \& G. Withers (Eds.), The Cambridge Economic History of Australia (pp. 73-96). Melbourne: Cambridge University Press. https://doi.org/10.1017/CHO9781107445222.008

Hunter, B. (2016). Some statistical context for analysis of CDEP. In K. Jordan (Ed.), Better Than Welfare? Work and Livelihoods for Indigenous Australians after CDEP (pp. 51-83). Canberra: ANU Press.

Jordan, K. (2016). Better Than Welfare? Work and livelihoods for Indigenous Australians after CDEP. Canberra: ANU Press. Retrieved from https://press.anu.edu.au/publications/series/centre-aboriginal-economic-policyresearch-caepr/better-welfare

Jordan, K., \& Altman, J. C. (2016). From welfare to work, or work to welfare? In K. Jordan (Ed.), Better Than Welfare? Work and Livelihoods for Indigenous Australians after CDEP (pp. 1-29). Canberra: ANU Press.

Keen, I. (Ed.). (2010). Indigenous Participation in Australian Economies. Canberra: ANU Press.

Kinnane, S., Harrison, J., \& Reinecke, I. (2015). Finger money: The black and white of stolen wages. Griffith Review, 47, 49-70.

Markham, F., \& Biddle, N. (2018a). Income, poverty and inequality (2016 Census Paper No. 2). Canberra: Centre for Aboriginal Economic Policy Research, ANU. Retrieved from http://caepr.cass.anu.edu.au/research/publications/income-poverty-and-inequality

Markham, F., \& Biddle, N. (2018b). Recent changes to the Indigenous population geography of Australia: evidence from the 2016 Census. Australian Population Studies, 2(1), 113. 
Moreton-Robinson, A. (2015). The White Possessive: Property, Power, and Indigenous Sovereignty. Minneapolis: University of Minnesota Press. Retrieved from https://www.upress.umn.edu/book-division/books/the-white-possessive Morphy, F., \& Sanders, W. (2004). The Indigenous Welfare Economy and the CDEP Scheme. Canberra: ANU Press. Retrieved from https://press.anu.edu.au/publications/series/centre-aboriginal-economic-policyresearch-caepr/indigenous-welfare-economy-and

Office of the Registrar of Indigenous Corporations. (2012). At the heart of art: a snapshot of Aboriginal and Torres Strait Islander corporations in the visual arts sector. Canberra: Office of the Registrar of Indigenous Corporations. Retrieved from http://www.oric.gov.au/publications/other-report/heart-art

Parijs, P. V. (2017). Basic Income: A Radical Proposal for a Free Society and a Sane Economy (1 edition). Cambridge, Massachusetts: Harvard University Press.

Sanders, W. (1988). The CDEP scheme: Bureaucratic politics, remote community politics and the development of an aboriginal 'workfare' program in times of rising unemployment. Politics, 23(1), 32-47. https://doi.org/10.1080/00323268808402044

Sanders, W. (1997). Opportunities and problems astride the welfare/work divide: the CDEP scheme in Australian social policy (Discussion Paper No. 141). Canberra: Centre for Aboriginal Economic Policy Research, ANU.

Sanders, W. (2012). Coombs' Bastard Child: The Troubled Life of CDEP. Australian Journal of Public Administration, 71(4), 371-391. https://doi.org/10.1111/14678500.12000

The Auditor General. (2017). Design and implementation of the Community Development Programme: Department of the Prime Minister and Cabinet, Department of Employment and Department of Human Services (ANAO Report No. 14, 2017-18). 
Canberra: Australian National Audit Office. Retrieved from

https://www.anao.gov.au/work/performance-audit/design-and-implementationcommunity-development-programme

Venn, D., \& Biddle, N. (2018). Employment outcomes (2016 Census Paper No. 5) (p. 30). Canberra: Centre for Aboriginal Economic Policy Research, ANU. Retrieved from http://caepr.cass.anu.edu.au/research/publications/employment-outcomes

Walter, M., \& Andersen, C. (2013). Indigenous statistics: a quantitative research methodology. Walnut Creek, CA: Left Coast Press. 